\title{
THE USE OF STATISTICAL GRAIN-SIZE METHOD IN ANALYSING BOREHOLE AND EVALUATING AQUIFER PARAMETERS. A CASE STUDY OF AJALI SANDSTONE FORMATION, SOUTHEASTERN NIGERIA
}

\author{
EMMANUEL O. EZIM, IZUCHUKWU I. OBIADI AND MIKE I. AKAEGBOBI
}

(Received 3 June 2016; Revision Accepted 19 January 2017)

\begin{abstract}
Several challenges abound with the accurate estimation of aquifer parameters in Groundwater resource development. This paper describes the investigation on the aquifer (mainly Ajali Sandstone Formation) parameters in Nsukka area. The Ajali Sandstone Formation is among the principal sources of groundwater in the area. The investigated area lies within Longitudes $7^{\circ} 22^{1} 30^{11} \mathrm{E}$ and $7^{\circ} 58^{1} 30^{11} \mathrm{E}$, and Latitude $6^{\circ} 73^{1} 30^{11} \mathrm{~N}$ and $7^{\circ} 00^{1} 00^{11} \mathrm{~N}$, covering an area of about 482 square kilometres. Sixty (60) cuttings from nine (9) boreholes drilled in the area were analysed texturally using statistical grain size method.

Results show that the highly permeable members of Ajali Sandstone are devoid of surface waters and are seen to be friable, medium-grained, poorly sorted, and highly cross-bedded. Recharge is mainly through rainfall. The distribution of major geological units, well log data, static water level data, and surface features were found to have influenced groundwater occurrence and flow pattern in the study area. The lithological logs showed sandy aquifers separated by clayey aquitards, while stratigraphic analyses of well lithological logs revealed the presence of at least four layers of contrasting hydraulic conductivity, making the aquiferous Ajali Sandstone homogenous and anisotropic. Values of permeability (k) from 0.00753 to $0.01512 \mathrm{~cm}^{2}$, hydraulic conductivity $(\mathrm{K})$ from 8.2886 to $16.6444 \mathrm{~m} / \mathrm{s}$, transmissivity $(\mathrm{T})$ between 455.87 and $1002.48 \mathrm{~m}^{2} \mathrm{~s}^{-1}$, and specific yield from 2.35 to $4.76 \mathrm{~m}^{3}$ were found to be consistently high, thus suggesting thick and prolific aquiferous zones.
\end{abstract}

KEYWORDS: Field Mapping -Borehole analysis -Textural analysis -Ajali Sandstone Aquifer -Nigeria

\section{INTRODUCTION}

One of the most common problems encountered in ground water resource development is the accurate estimation of transmissivity $(\mathrm{T})$ and hydraulic conductivity $(\mathrm{K})$ of aquifers. These parameters together with the storage coefficient (S), as noted by Uma et al. (1989) are the basic tools needed to assess the potential yield of aquifers over a long period of exploitation. The investigation was carried out in the University of Nigeria, Nsukka community including Nsukka metropolis and environs, in Enugu State, Southeastern Nigeria. They lie within Longitudes $7^{\circ}$ $22^{1} 30^{11} \mathrm{E}$ and $7^{\circ} 58^{1} 30^{11} \mathrm{E}$, and Latitude $6^{\circ} 73^{1} 30^{11} \mathrm{~N}$ and $7^{\circ} 00^{1} 00^{11} \mathrm{~N}$, with an aerial extent of about 482 square kilometres. The study area is surrounded by some towns including Obukpa, Orba, Lejja, Ibagwa, Ovoko, Ede Oballa and Opi. It is accessible through several major roads of which some include: Enugu-Obollo AforMarkurdi express Road, Nsukka - Opi Road, Nsukka Ngurugu Road. There are many other minor road networks and pathways. Some of these secondary and minor roads are motorable but becomes inaccessible during the rainy season.

The scope and the objectives of the study involve making further study with regard to the general geology, physiography, borehole analysis and evaluating the Ajali Sandstone Aquifer parameters using statistical grain-size method. Collection of borehole samples to determine several hydrological parameters and the depositional processes have been carried out as well as statistical and mathematical analyses of the rock grain sizes aimed at delineating the aquifer systems in the area.

Attempts have also been made to further evaluate the hydrogeological and environmental problems such as erosion, inherent in the area and suggesting possible solutions that will also facilitate effective planning, supply, and management of the water resources. In the process of meeting the above objectives, aquifer characteristics such as aquifer thicknesses and depth to water table as well as static water level, were evaluated. Aquifer parameters such as hydraulic conductivity $(\mathrm{K})$ and transmissivity $(\mathrm{T})$ were established within the limits of the available data and information collected.

It has been established by Nwajide and Reijers (1996) that the Nsukka area lies within the Anambra Basin. A basin, of which several authors including Agagu et al. (1985), Ladipo(1987a), Nwajide and Reijers(1996), found to have formed during the Santonian tectonism about eighty five million years ago

Emmanuel O. Ezim, Department of Geology, University of Ibadan, Ibadan, Nigeria

Izuchukwu I. Obiadi, Geological Science Department, NnamdiAzikiwe University, P.M.B. 5025, Awka, Nigeria

Mike I. Akaegbobi, Department of Geology, University of Ibadan, Ibadan, Nigeria 
( 85ma), resulting in the folding and uplifting of the Abakaliki-Benue Trough and subsidence of the Anambra Platform.

Nwajide and Hoque (1976) reported that the textural properties of the Ajali Sandstone are composed of medium-coarse grained sandstones, sub-angular to sub-rounded quartz arenites. Also, Ladipo (1986) researched on the Tidal Shelf depositional mode for Ajali Sandstone and inferred that the formation was likely deposited in an environmental spectrum probably ranging from marine through transitional to continental. Potter and Pettijohn (1975) gave some methods of collecting structural data in the field and the statistical analysis of these data. Environmental interpretations of the Ajali Sandstone have suggested fluvial and fluvialdeltaic depositional models (Reyment, 1965; Murat, 1972; and Ezepue, 1977).

Egboka (1983) studied the groundwater resources of the Nsukka area and environs while Egboka et al. (1989) evaluated the hydraulic conductivity of sandy aquifers in the Nsukka area using the new statistical grain-size method. Their findings suggest that the hydraulic conductivity $(\mathrm{K})$ of the Ajali Sandstone is in the order of $1 \times 10^{-2} \mathrm{~cm} / \mathrm{s}$, while the permeability is between $2.0 \mathrm{~cm}^{2}$ to $20.7 \times 10^{-10} \mathrm{~cm}^{2}$. Borehole analysis and geophysical characterization of the Anambra Basin has been done by several researchers, including Onwuemesi (1990).

\section{CLIMATE, PHYSIOGRAPHY AND GEOLOGY}

The study area lies within the rainforest belt of Nigeria with the rainy and dry seasons. The dry season runs through the months of November to March, and the rainy season from April to October; with a short period of reduced rains in August commonly referred to as "August break". Inyang (1975) placed the area within the fourth region of the five climatic regions classification. This fourth region is characterized by dry periods of low precipitation and reduced infiltration. High temperatures, low relative humidity and high evapotranspiration also characterize the dry period. Also, the wet period is characterized by moderate temperatures and high relative humidity of about 80 to $90 \%$, while the dry period is characterized by high temperatures and lower relative humidity ranging from $50 \%$ to $80 \%$. The mean temperature value ranges from $22^{\circ} \mathrm{C}$ to $35^{\circ} \mathrm{C}$, with daytime temperature range of 17 to $28^{\circ} \mathrm{C}$; while the mean atmospheric pressure is about $1011 \pm 1.2$ Millibars (Inyang, 1975).

The physiography is made up of the Residual hills, the lowlands and the dry valleys. Ofomata (1967) had identified five types of these residuals according to their shapes: dome, conical, ridges, flat-topped or 'mesa-like' and 'cuesta-like'. The summit of these hills, especially, where they are flat-topped as well as on the ridges are covered by iron-stone concretions which make them more resistant. The differences in the shapes of the residual features were highlighted in the study according to Ofomata (1973).

The greater portions of the study area comprises the lowlands with elevation of about $125 \mathrm{~m}$ above sea level and these areas serve as good channels for water which tends to run off during the rainy season. The lowland areas are made up of red earth and sediments, which are weathered and eroded from the upper lateritic cap. The grain sizes of sediments range from silt to conglomeritic, as a result of products of the materials eroded from the outliers.

Also, the dry valleys are Wider, flat-bottomed and spreads all over the surface of the plateau. The dry valleys and the residual hills form an extensive escarpment referred to as the Nsukka-Okigwe Cuesta (Fig. 1). Presently these valleys are dry inferring a sudden disappearance of the rivers that carved them. The geogenic (geological, geotechnical, hydrogeochemical) and anthropogenic factors have greatly contributed to gully development and growth. Heavy rainfall (between $1750 \mathrm{~mm}$ to $2500 \mathrm{~mm}$ ) could also be a factor that causes a rise in the water table. The hydraulic head produces rapid flow rate that enhances the gulling process, initiated by narrow channels, which rapidly widened with time. This process; undoubtedly lead to the development of major gullies that have recently approached mature stage. The erosion (that is, the gulling process) is followed by mass movement and sediments removal, mainly by flood flows that occur during rainy

season.

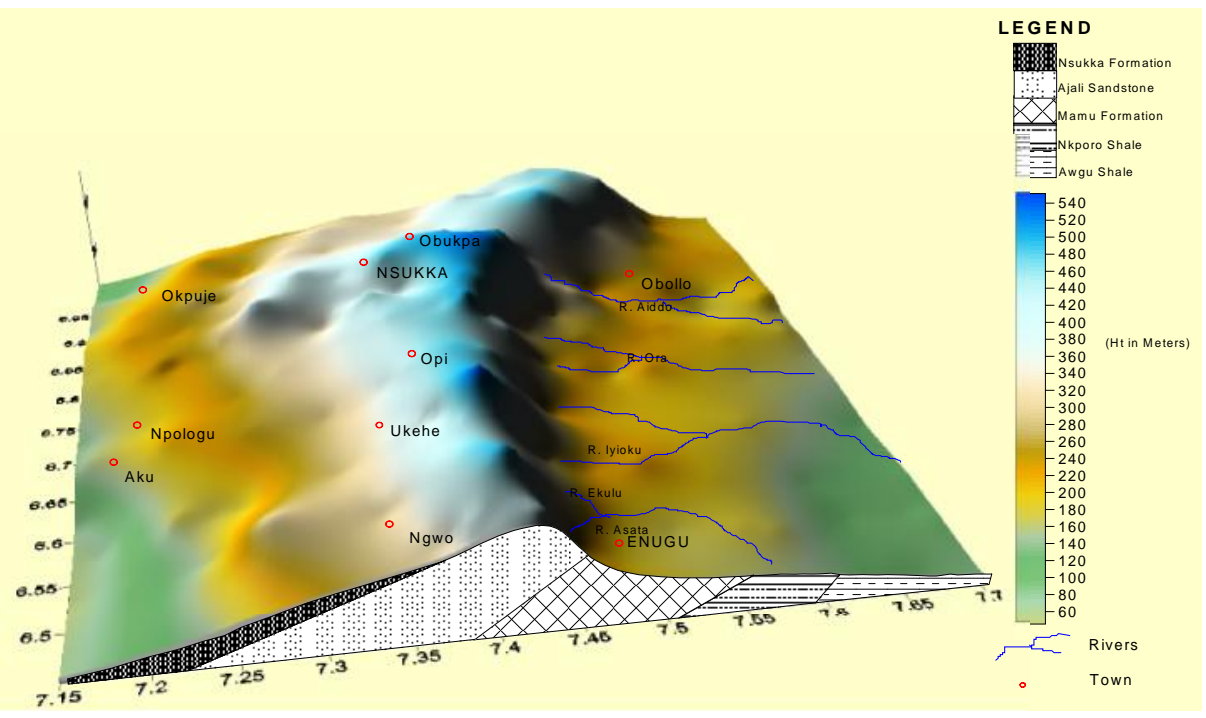

Figure 1: Nsukka section of the Nsukka-Okigwe Cuesta. 
It will be worthwhile to note that vegetation cover affects the rate of erosion and also disparity in the vegetation-cover exists in most parts. The vegetation is dense in the low-lying shaley terrains thus greatly hindering erosion. But in the hilly and sandy areas, there are sparse vegetations, making them more prone to erosion.

The Nsukka area, geologically, lies within the Anambra Basin; an inland sedimentary basin sandwiched between the Southwestern part of the Benue Trough and the Petroliferous Niger Delta. The origin, sedimentology and stratigraphy of the basin have been well presented by several authors, such as Murat, (1972), Kogbe, (1989b), Agagu et al. (1985), and
Nwajide, (2006a). The basin is bounded in the west by the Precambrian Basement Complex, of western Nigeria, and in the east by the Abakaliki Anticlinorium. The Southern boundary is at Onitsha which coincides with the northern boundary of the Niger Delta Basin, while the northern boundary is taken to correspond to the limit of the exposure of the Maastrichtian sediments (Nwajide, 2006a). The basin is exposed over a roughly triangular territory estimated at some $95,000 \mathrm{~km}^{2}$. It rests on the Awgu Formation of the southern Benue Trough (in an angular unconformity relationship), but underlies the Niger Delta Basin for a considerable extent. The total area is possibly in excess of $140,000 \mathrm{~km}^{2}$,

2).

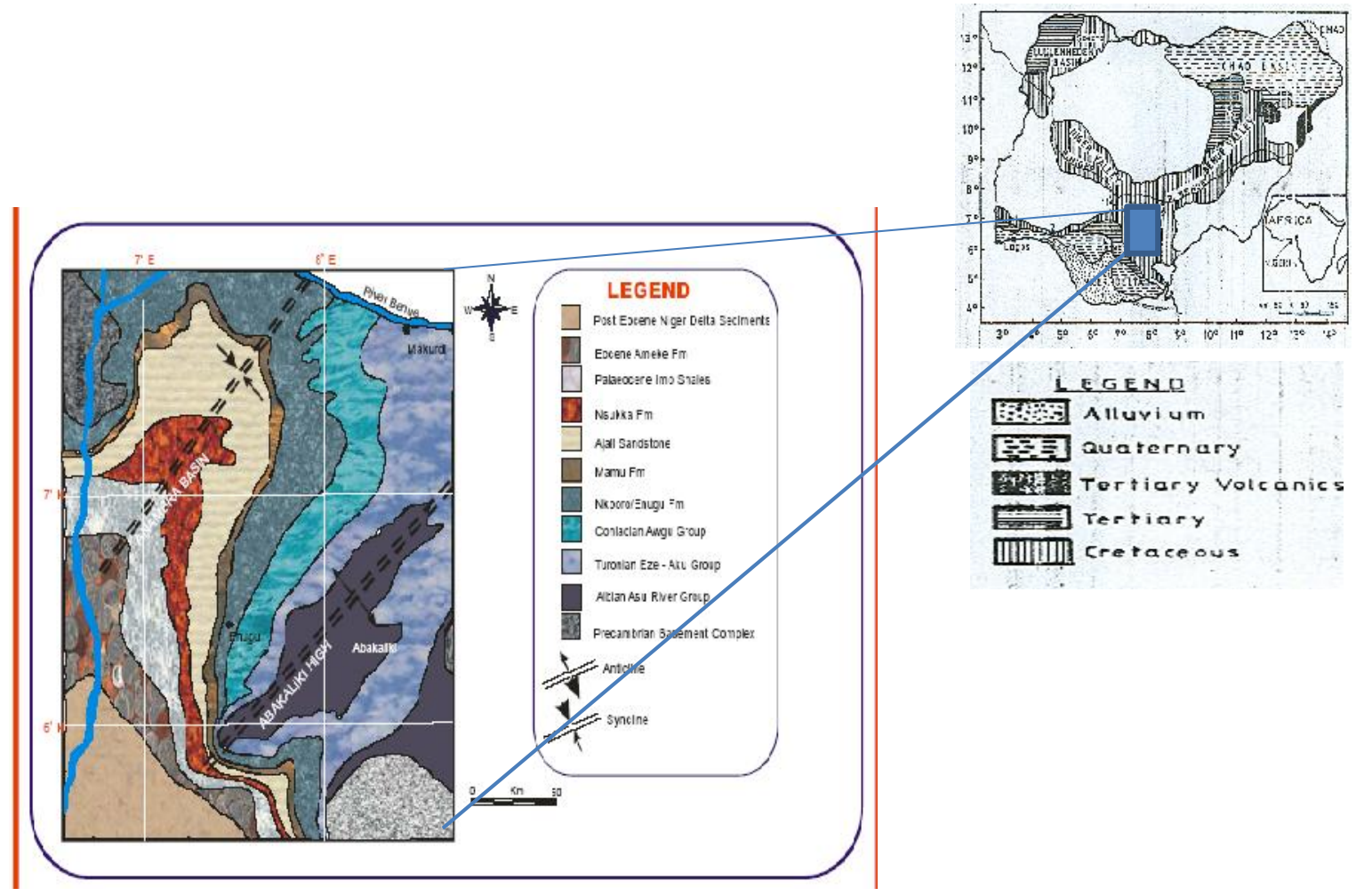

Figure 2: Geological map of Southeastern Nigeria showing the Southern Benue Trough and Anambra Basin, (Modified after Burke et al, 1972, Kogbe, 1989b, and Nwajide, 2006a).

Amongst the sediments of the basin are the Mamu Formation, Ajali Sandstone, Nsukka Formation. Slow subsidence followed by a major regression led to the deposition of the Mamu (coal-bearing) and Ajali Formations which accumulated during the Maastrichtian. The overlying Ajali Sandstone has been attributed to fluvial deposition, and the development of shallow marine sub tidal sand bars (Ladipo, 1986; Nwajide, 2006a). The Danian Epoch of the Palaeocene period saw the deposition of the Nsukka Formation. Sedimentation was mainly of fluvial origin (Nwajide and Reijers, 1996; Nwajide, 2006a) (Table 1). The borehole data in the southern parts of the Anambra Basin used in the reconstruction of the stratigraphic unit reveals that the formations (i.e. Mamu, Ajali and Nsukka) all appear to be steeply inclined and dipping towards the western flank of Onitsha High, and flattening out below the Imo Formation,

(Fig.
2). 
Table 1: Lithostratigraphic Units of the Anambra Basin (Modified from Nwajide 2006a).

\begin{tabular}{|c|c|c|c|c|c|c|c|c|}
\hline Age & Basin & \multicolumn{7}{|c|}{ Stratigraphic Units } \\
\hline Thanetian & \multirow[t]{2}{*}{$\begin{array}{l}\text { Niger } \\
\text { Delta }\end{array}$} & \multicolumn{7}{|c|}{ Imo Formation } \\
\hline \multicolumn{8}{|l|}{ Danian } & \\
\hline & \multirow{6}{*}{$\begin{array}{l}\text { Anambra } \\
\text { Basin }\end{array}$} & \multirow[t]{5}{*}{$\begin{array}{l}\text { Coal } \\
\text { Measures }\end{array}$} & \multirow{2}{*}{\multicolumn{6}{|c|}{ Nsukka FormatIon }} \\
\hline \multirow[t]{3}{*}{ Maastrichtian } & & & & & & & & \\
\hline & & & \multicolumn{6}{|c|}{ AjalI Formation } \\
\hline & & & \multicolumn{6}{|c|}{ Mamu FormatIon } \\
\hline \multirow[t]{2}{*}{ Campanian } & & & & & & & & \\
\hline & & $\begin{array}{l}\text { Nkporo } \\
\text { Fm. }\end{array}$ & $\begin{array}{l}\text { Nkporo } \\
\text { Shale }\end{array}$ & $\begin{array}{l}\text { Enugu } \\
\text { Fm. }\end{array}$ & $\begin{array}{l}\text { Owelli } \\
\text { S St. }\end{array}$ & $\begin{array}{l}\text { Afikpo } \\
\text { S St. }\end{array}$ & $\begin{array}{l}\text { Otobo } \\
\text { S St. }\end{array}$ & $\begin{array}{l}\text { Lafia } \\
\text { S St. }\end{array}$ \\
\hline Santonian & $\begin{array}{l}\text { Southern } \\
\text { Benue } \\
\text { Trough }\end{array}$ & \multicolumn{7}{|c|}{ Awgu FormatIon } \\
\hline
\end{tabular}

The Ajali Formation consists of thick friable, poorly sorted sandstone typically white in colour but sometimes Iron-stained. Marked bandings of coarse and fine layers are displayed. The sand grains and large fragments are sub-angular, with a sparse cement of white clay. Large-scale, cross bedding is also one of its characteristic features (Banerjee, 1979; Amajor, 1984; Kogbe, 1989b). The Ajali Formation is well displayed along the lowland and dry valley zones of the study area including: Ede-Oballa, Obukpa, Onuiyi Road, Ibagwa Road, Obollo Road, Base of the Physics observatory, Odim area, and beyond Zik's flat. The thickness of the Ajali Formation has been measured by several workers. According to Nwajide (2006a), maximum recorded thickness was from the Igbariam borehole where the formation is up to $534 \mathrm{~m}$ thick. This thickness decreases gradually towards the west and east to only a few tens of metres around Okigwe. Also, Egboka (1983) gave a thickness of $300 m+$ for this Formation.

The depositional environment of the Ajali Sandstone as described by some authors include: a fluvio-deltaic depositional environment (Ladipo, 1986; Agagu et al, 1985), an inert tidal bar and channel system (Barnejee, 1979), an inter-tidal flat, based strictly on its sedimentary facies characteristics (Amajor, 1984). The overlying lateritic Nsukka Formation consists of an alternating succession of sandstone, dark shale, sandy shale, thin coal-seams at various horizons and thin beds of limestone towards the top (Murat, 1972; Kogbe, 1989b; Nwajide, 2006a). The beds are generally gently dipping (amount of dip ranging from $1^{0}$ to $6^{0}$ ).

\section{Hydrogeologic Setting of the Study Area}

The Ajali Sandstone Aquifer is essentially unconfined in most of the areas. Results of geo-electric resistivity surveys (Onwuemesi, 1990) and static water level measurements in the relatively shallow boreholes near the crest of the escarpment indicate that the water table lies at a depth of about $55 \mathrm{~m}$. The saturated thickness of the aquifer is about $85 \mathrm{~m}$. Although the Ajali Sandstone Formation shows a wide textural variation across its thickness, borehole data show that below the water table the texture is relatively more homogenous and ranges only from fine to medium grain. Thus, within its saturated thickness, the hydraulic conductivity could range from $10^{-5}$ to $10^{-4} \mathrm{~m} / \mathrm{s}$. Values ranging from $7 \times 10^{-5}$ to $2 \times 10^{-3} \mathrm{~m} / \mathrm{s}$ were obtained by Uma et al. (1989), using grain size data. It would appear however, that the upper limits of this range reflects the gravely and coarse sand units which predominate in the region above water table. The data used were from the sandy aquifers of the southeastern sedimentary basin of Nigeria. The formation was selected because of its varied geologic and hydrogeologic environments. The aquifer fall into the first class group as was described in Uma et al. (1989).

\section{METHODOLOGY}

\section{Field Study and Data Acquisition}

Series of reconnaissance surveys were carried out in different stages of the study. The early stage was done between 10th and 14th April. During this time, familiarization visits were made to establish network of roads and possible lithological boundaries. Also, the topographic and base maps of the region were initially obtained on scale of 1:250,000.Several bore-holes were found to be drilled in the study area. While some were on-going, the rest had been completed as at the time of this investigation. The positions and the elevations of these locations (that is, the borehole sites) were determined with the Global Positioning System (GPS) device.

The distribution of the main geological units were studied during the field work stage, which included visits made on the borehole sites. The Geological 
formations/outcrops were examined in the cliffs, valley walls, hills and some road cuts.

Effort was made to sample good outcrop surfaces. In order to study the various stratigraphic units, the description of outcrops, the aquifer parameters (including porosity and permeability), and analysis on the inherent structural features were made including studying the drainage pattern. Fractures, joints and other features were also noted with the aid of a field note. Some studies were carried out in the borehole sites during the drilling and completion stages. These include: observation of the borehole samples, noting their properties (colour, texture variation, etc.) and even the critical analysis of the penetration speed, period of arrival of the cuttings to the surface and the overall drilling processes. Some of the samples/cuttings were collected at the intervals of ten (10) feet deep while others were collected at every three (3) metres. Details of lithological successions of the formation are based on data from these exploratory wells drilled by different companies.

Textural Analysis of rock samples, were carried out in the Sedimentology laboratory on sandstones collected from each of the boreholes between the depths of 250-700feet ( 76m-213m).

\section{DATA ANALYSES}

Textural Analysis

Grain size is a fundamental attribute of siliciclastic sedimentary rocks and thus one of the important descriptive properties of such rocks. Sedimentologists are particularly concerned with three aspects of the grain size analyses:

1. Measuring grain size and expressing it in terms of forms and sizes of grains or grade scale.

2. Summarizing large amounts of grain size data and presenting them in graphical or statistical form for easy interpretation.

3. Evaluating the genetic significance of these data.

The grain size scale used was the universal Udden-Wentworth scale. The scale, which extends from values less than $1 / 256 \mathrm{~mm}(0.0039 \mathrm{~mm})$ to values greater than $256 \mathrm{~mm}$, is divided into four major size categories. They include: clay $(0.00006-0.0039 \mathrm{~mm})$, silt $(0.0039-0.0625 \mathrm{~mm})$, sand $(0.00625-2.00 \mathrm{~mm})$, and gravel (2.00 - 256mm) (Boggs, 2005).A useful modification of the Udden-Wentworth scale is the logarithmic Phi scale which was proposed by Krumbein in 1934. This scale, which allows grain size data to be expressed in units of equal values for the purpose of graphical plotting and statistical calculations, is based on the following relationship:

$\emptyset=-\log 2 d$

Where, $\phi$ is the Phi size and $d$ is the grain diameter measured in millimetres $(\mathrm{mm})$.

Calculating Grain-size Statistical Parameters by graphical methods

This method (Folk's and Ward's Formula) was modified by Boggs (2005). The method analyzes:

Measure of the mean size (M),

$M z=\frac{\emptyset 16+\emptyset 50+\emptyset 84}{3}$

Where $M z=$ graphic mean

1. The median diameter (MD): The size at which $50 \%$ of the particles (by weight) are coarser and the remainder finer.

Median diameter, $M D=\emptyset 50$

3. The measure of uniformity $\left(\sigma_{i}\right): A$ measure of the spread of grain sizes about the average and it defines the dispersion of sediment [Inclusive Graphic Standard Deviation $\left(\sigma_{i}\right)$ or Sorting]. The best sorting attained by natural sediments ranges from 0.2 to 0.25 , for beach and dune sands, while the poorest sorted sediments (mud flows, glacial tills) have standard deviation range of 5.00 to 8.00 . Inclusive Graphic Standard Deviation $\left(\sigma_{i}\right)$ is expressed as below:

$\sigma_{i}=\frac{\varnothing 84-\emptyset 16}{4}+\frac{\emptyset 95-\emptyset 5}{6.6}$

4. Measure of skewness(Ski): Defined as the degree of symmetry or a measure of the asymmetry of the frequency distribution. It can also be referred to as Inclusive graphic skewness (Ski) and can be expressed in terms of $\mathrm{Phi}$ as shown below:

$S k i=\frac{(\emptyset 84+\emptyset 16-2 \emptyset 50)}{2(\emptyset 84-\emptyset 16)}-\frac{(\varnothing 95+\emptyset 5-2 \emptyset 50)}{2(\emptyset 95-\emptyset 5)}$

5. The measure of kurtosis/Graphic Kurtosis $\left(\mathrm{K}_{\mathrm{G}}\right)$ : The degree of peakedness of a cumulative curve. It measures the degree of sorting in the centre of the curve compared to sorting in its tails. It is mathematically expressed as:

Graphic Kurtosis $K_{G}=\frac{(\emptyset 95-\emptyset 5)}{2.44(\emptyset 75-\emptyset 25)}$

Note that the verbal scale and descriptive terms for these grain-size statistical parameters can be found in details in Boggs (2005).In this work, 100grammes $(100 \mathrm{~g})$ of each of the sixty $(60)$ borehole samples were sieved using Motorized Mechanical Sieve Shaker (MMSS) for about twenty (20) minutes. The retained weights in sieves were measured. The weights were then converted to cumulative weight percentages after correction. Data from sieve analysis are presented graphically and cumulative frequency curves plotted on the log probability scaled graphs. From these graphs, statistical parameters were obtained using Folk and Ward's formula. Values for mean, median, standard deviation, skewness and kurtosis were hence calculated using the Folk and Ward's formulae and then presented in table 2. 
Table 2: Results of the Textural Analysis of samples from selected Boreholes

A02 at Abuja Building

\begin{tabular}{|c|c|c|c|c|c|c|}
\hline S/No. & $\begin{array}{c}\text { Sample } \\
\text { No./Depth(ft) }\end{array}$ & Mean Size $\left(\mathbf{M}_{\mathrm{Z}}\right)$ & $\begin{array}{r}\text { Medi } \\
\text { an }\left(\phi_{50}\right)\end{array}$ & Sorting $(\sigma)$ & Skewness (Ski) & Kurtosis $\left(\mathbf{K}_{\mathbf{G}}\right)$ \\
\hline 1 & A02D250 & 1.10 Medium sand & 1.00 & 0.392 Well sorted & 0.414 Strongly fine skewed & 1.465 Leptokurtic \\
\hline 2 & A02D300 & 0.23 Coarse sand & 0.10 & 0.511 Moderately well sorted & 0.427 Strongly fine skewed & 1.068 Mesokurtic \\
\hline 3 & A02D350 & 0.28 Coarse sand & 0.13 & 0.463 Well sorted & 0.534 Strongly fine skewed & 1.021 Mesokurtic \\
\hline 4 & A02D400 & 0.96 Coarse sand & 0.94 & 0.390 Well sorted & 0.127 Fine skewed & 1.662 Very LeptoKurtic \\
\hline 5 & A02D450 & 0.79 Coarse sand & 0.80 & 0.294 Very well sorted & 0.020 Near symmetrical & 1.383 Leptokurtic \\
\hline 6 & A02D500 & 0.80 Coarse sand & 0.82 & 0.284 Very well sorted & 0.486 Strongly fine skewed & 1.610 Very LeptoKurtic \\
\hline 7 & A02D550 & 0.57 Coarse sand & 0.57 & 0.556 Moderately well sorted & 0.077 Near symmetrical & 0.967 Mesokurtic \\
\hline 8 & A02D600 & 0.23 Coarse sand & 0.19 & 0.347 Very well sorted & 0.299 Fine skewed & 0.982 Mesokurtic \\
\hline 9 & A02D650 & 0.36 Coarse sand & 0.28 & 0.322 Very well sorted & 0.463 Strongly fine skewed & 0.953 Meso kurtic \\
\hline 10 & A02D700 & 0.17 Medium sand & 0.10 & 0.452 Well sorted & 0.288 Fine skewed & 1.308 Lepto kurtic \\
\hline \multicolumn{7}{|c|}{ F03 at Franco refractory } \\
\hline S/No. & $\begin{array}{c}\text { Sample } \\
\text { No./Depth(ft) }\end{array}$ & Mean Size $\left(M_{Z}\right)$ & $\begin{array}{r}\text { Medi } \\
\text { an }\left(\phi_{50}\right)\end{array}$ & 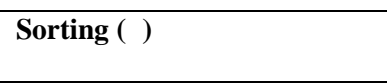 & Skewness (Ski) & Kurtosis $\left(K_{G}\right)$ \\
\hline 1 & F03D250 & 0.32 Coarse sand & 0.20 & 0.628 Moderately well sorted & 0.264 Fine skewed & 1.076 Mesokurtic \\
\hline 2 & F03D300 & 0.62 Coarse sand & 0.60 & 0.646 Moderately well sorted & 0.020 Near symmetrical & 1.048 Mesokurtic \\
\hline 3 & F03D350 & 0.28 Coarse sand & 0.13 & 0.463 Well sorted & 0.534 Strongly fine skewed & 1.021 Mesokurtic \\
\hline 4 & F03D400 & 0.68 Coarse sand & 0.60 & 0.595 Moderately well sorted & 0.298 Fine skewed & 1.189 Leptokurtic \\
\hline 5 & F03D450 & 0.78 Coarse sand & 0.75 & 0.580 Moderately well sorted & 0.109 Fine skewed & 0.948 Mesokurtic \\
\hline 6 & F03D500 & 0.93 Coarse sand & 0.90 & 0.483 Well sorted & 0.144 Fine skewed & 1.290 Leptokurtic \\
\hline 7 & F03D550 & 0.57 Coarse sand & 0.57 & 0.556 Moderately well sorted & 0.077 Near symmetrical & 0.967 Mesokurtic \\
\hline 8 & F03D600 & 0.84 Coarse sand & 0.80 & 0.521 Moderately well sorted & 0.160 Fine skewed & 0.964 Mesokurtic \\
\hline 9 & F03D650 & 0.36 Coarse sand & 0.28 & 0.322 Very well sorted & 0.463 Strongly fine skewed & 0.953 Meso kurtic \\
\hline 10 & F03D700 & 0.17 Medium sand & 0.10 & 0.452 Well sorted & 0.288 Fine skewed & 1.308 Lepto kurtic \\
\hline \multicolumn{7}{|c|}{ Z01 at Zenith Enugu Rd. Nsukka } \\
\hline S/No. & $\begin{array}{c}\text { Sample } \\
\text { No./Depth(ft) }\end{array}$ & Mean Size $\left(M_{z}\right)$ & $\begin{array}{r}\text { Medi } \\
\text { an }\left(\phi_{50}\right)\end{array}$ & Sorting $(\sigma)$ & Skewness (Ski) & Kurtosis $\left(\mathbf{K}_{\mathbf{G}}\right)$ \\
\hline 1 & Z05D250 & 0.16 Coarse sand & -0.2 & 0.703 Moderately well sorted & 0.126 Fine skewed & 0.922 Mesokurtic \\
\hline 2 & Z05D300 & -0.79 Coarse sand & -0.80 & 0.575 Moderately well sorted & -0.028 Near symmetrical & 1.189 Leptokurtic \\
\hline 3 & Z05D350 & 0.35 Coarse sand & 0.24 & 0.613 Moderately well sorted & 0.244 Fine skewed & 1.195 Lepto kurtic \\
\hline 4 & Z05D400 & 0.27 Coarse sand & 0.20 & 0.300 Very well sorted & 0.440 Strongly fine skewed & 1.393 Leptokurtic \\
\hline 5 & Z05D450 & 0.95 Coarse sand & 0.90 & 0.710 Moderately sorted & 0.100 Near symmetrical & 1.100 Mesokurtic \\
\hline 6 & Z05D500 & 1.02 Medium sand & 0.90 & 0.724 Moderately sorted & 0.300 Fine skewed & 1.30 Leptokurtic \\
\hline 7 & Z05D550 & 1.07 Medium sand & 1.00 & 0.440 Well sorted & 0.273 Fine skewed & 1.303 Leptokurtic \\
\hline 8 & Z05D600 & 1.21 Medium sand & 1.10 & 0.696 Moderately well sorted & 0.249 Fine skewed & 1.105 Mesokurtic \\
\hline 9 & Z05D650 & 1.17 Medium sand & 1.17 & 0.720 Moderately sorted & 0.023 Near symmetrical & 1.113 Leptokurtic \\
\hline 10 & Z05D700 & 1.29 Medium sand & 1.11 & 0.522 Moderately well sorted & 0.483 Strongly fine skewed & 1.078 Mesokurtic \\
\hline
\end{tabular}




\section{Porosity and Transmissivity}

When stratigraphic units are composed of materials of varying particle sizes (clay, silt, sand, gravel, and cobbles), void spaces exist between particles. The volume of void spaces of a stratigraphic unit is its porosity. The smaller the particle sizes of the material composing a unit (such as a clay unit) the higher the porosity (resulting in higher fluid content) and vice versa (Freeze and Cherry, 1979; Akudinobi and Egboka, 1996). Transmissivity is obtained from the relation $T=K b$ where $\mathrm{T}=$ transmissivity $\left(\mathrm{m}^{2} / \mathrm{s}\right), \mathrm{K}=$ Hydraulic conductivity $(\mathrm{m} / \mathrm{s})$ and $\mathrm{b}=$ aquifer thickness $(\mathrm{m})$.

\section{Aquifer parameter Methods}

The hydraulic conductivity, $\mathrm{K}$, could be calculated following any of the methods described by Hazen (1893), Harleman et al. (1963), and Uma et al. (1989); see Tables 3,4 and 7 .

Hazens (1893) Method: The method relies on the effective grain size $\left(d_{10}\right)$ and predict a power relationship between $\mathrm{d}_{10}$ and $K=A d_{10}^{2}$. Where $\mathrm{A}$ is empirical constant representing the effects of all other textual and digenetic attributes. It works well for loose, recent materials and it is assigned a value of 100 . (Note: $A$ is same as $C$ )

Harlemann et al. (1963) Method: This method is similar to that of Hazen (1893), but the relating equation is of the form: $K=C d_{10}^{2}$ where $\mathrm{C}$ is the coefficient as in Hazen and is equal to $6.54 \times 10^{-4}$.

Kozeny Carman in Bear (1972): $\mathrm{C}=64.1$

Uma et al. (1989) Method: Similar to Hazen's and Harlemann's methods, but compensated for the effects of digenesis, which is common in geologically old materials. The empirical equation is of the form: $K=$ $C d_{10}^{2}$, where $\mathrm{C}=6.1$ for loose to unconsolidated materials; 3.8 for completely consolidated materials, and 2.0 for fairly well consolidated materials. The $\mathrm{k}, \mathrm{K}$ and $\mathrm{T}$ of the aquifers in the area have been calculated using the different methods reviewed above.

\section{Borehole Analysis}

Spontaneous Potential (SP) Logging and Resistivity Logging were carried out. SP-log is simply a voltmeter measurement of voltage or electrical potential difference between the mud in the hole at a particular depth and a ground stake driven into the surface of the earth, a short distance from the borehole. In SP logging, an SP probe measures the voltage developed as a response to electrochemical effects of differences in borehole fluid and oxygen reduction of minerals. Movement of pore fluids also produces voltages. Hence, the resulting log curve reflects the permeability of the rocks and indirectly, their lithology.

Also, the electrical resistivity of soil, rock, and pore fluids were measured and the identification of lithology and stratigraphic correlation carried out. Clay content of the earth materials may be measured based on resistivity, and porosity may be estimated with respect to its fluid content. Contaminant level in soil and rock can be measured based on fluid conductivity. Like the SP, the Resistivity logs (Laterolog and Induction log) are usually run in fluid-filled, uncased boreholes.

Laterolog tools send an electric current from an electrode on the sonde directly into the formation. The return electrodes are located either on surface or on the sonde itself. Actually, since the resistivity of the mud is measured in series with the resistivity of the formation, Laterolog tools give best results when mud resistivity is low with respect to formation resistivity (i.e. in salty mud).

\section{RESULTS AND DISCUSSION}

\section{Borehole depths and static water levels}

The summary of the results of the aquifer characterisation is presented in Tables 3, 4 and 6, while the selected borehole logs are presented in figures 3, 4, 5 and 6 . The results indicate that most of the boreholes including those at Abuja Building (A02), Franco Refactory (F03) and the Energy Centre (E04), all penetrated the Ajali Sandstone aquifer; with respective depths up to $720 \mathrm{ft}(220 \mathrm{~m}), 670 \mathrm{fts}(210 \mathrm{~m})$ and $682 \mathrm{fts}$ $(208 \mathrm{~m})$. Also, static water levels were determined and they fall within the range of $500-550 \mathrm{ft}, 350-400 \mathrm{ft}$, and $485 \mathrm{ft}$ respectively (Figs. 3, 4 and 5). Similarly, the borehole (Z05) at ZENITH BANK (along Enugu Road, Nsukka), was drilled to a depth of $656 \mathrm{ft}$ (approximately $200 \mathrm{~m}$ ), penetrated the Ajali Sandstone aquifer as well and having a static water level determined to be in the range of 580 to 600 ft (Fig. 6). 


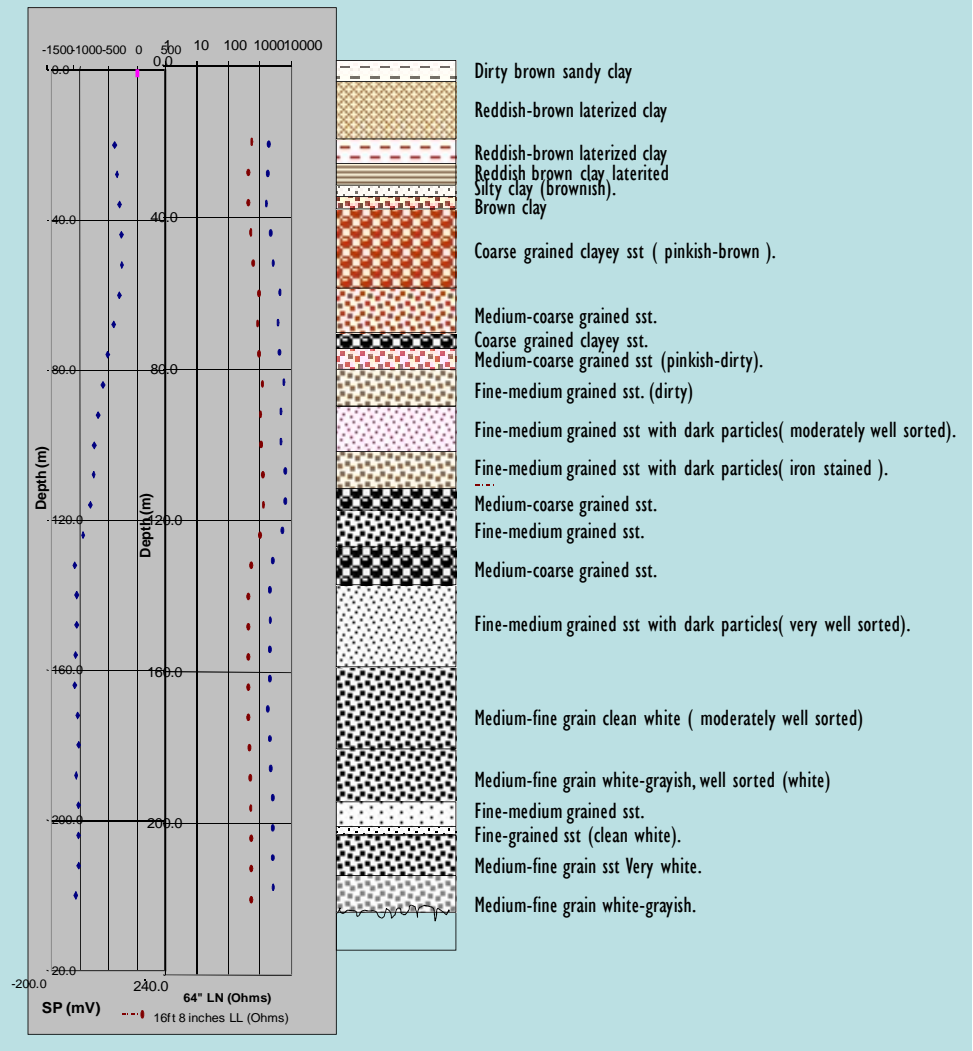

Figure 3: Log and lithological results of the borehole (A02) at Abuja Building, University of Nigeria, Nsukka.

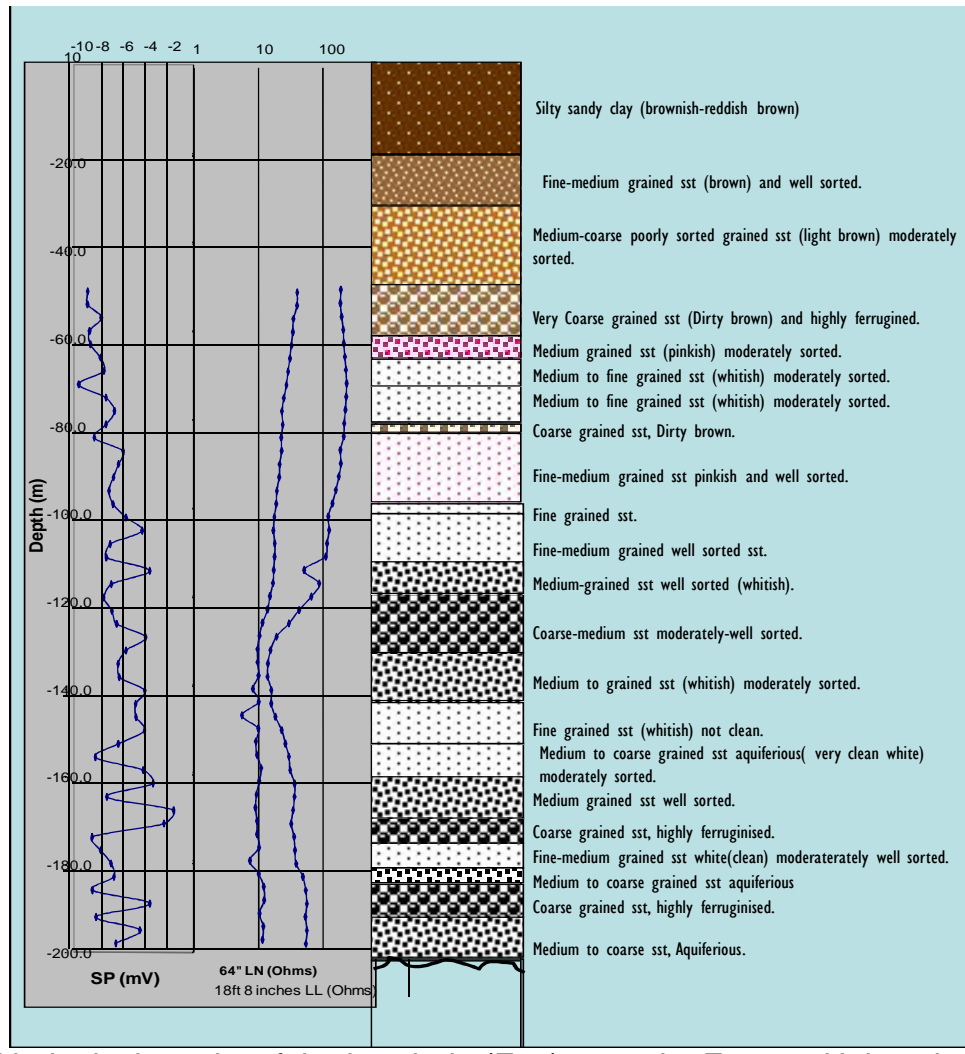

Figure 4: Log and lithological results of the borehole (F03) opposite Franco, University of Nigeria, Nsukka. 


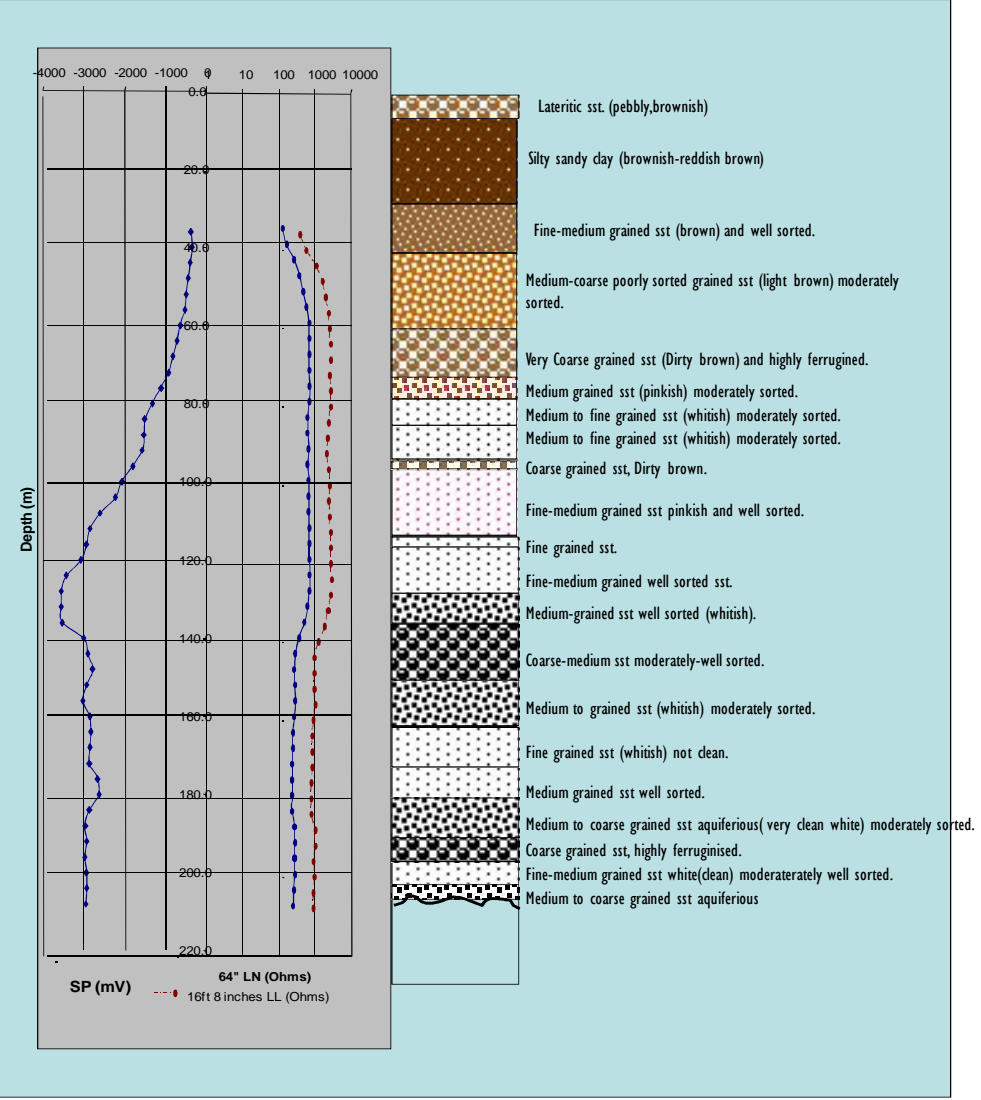

Figure 5: Log and lithological results of the borehole (E04), at the Energy Centre, University of Nigeria, Nsukka.

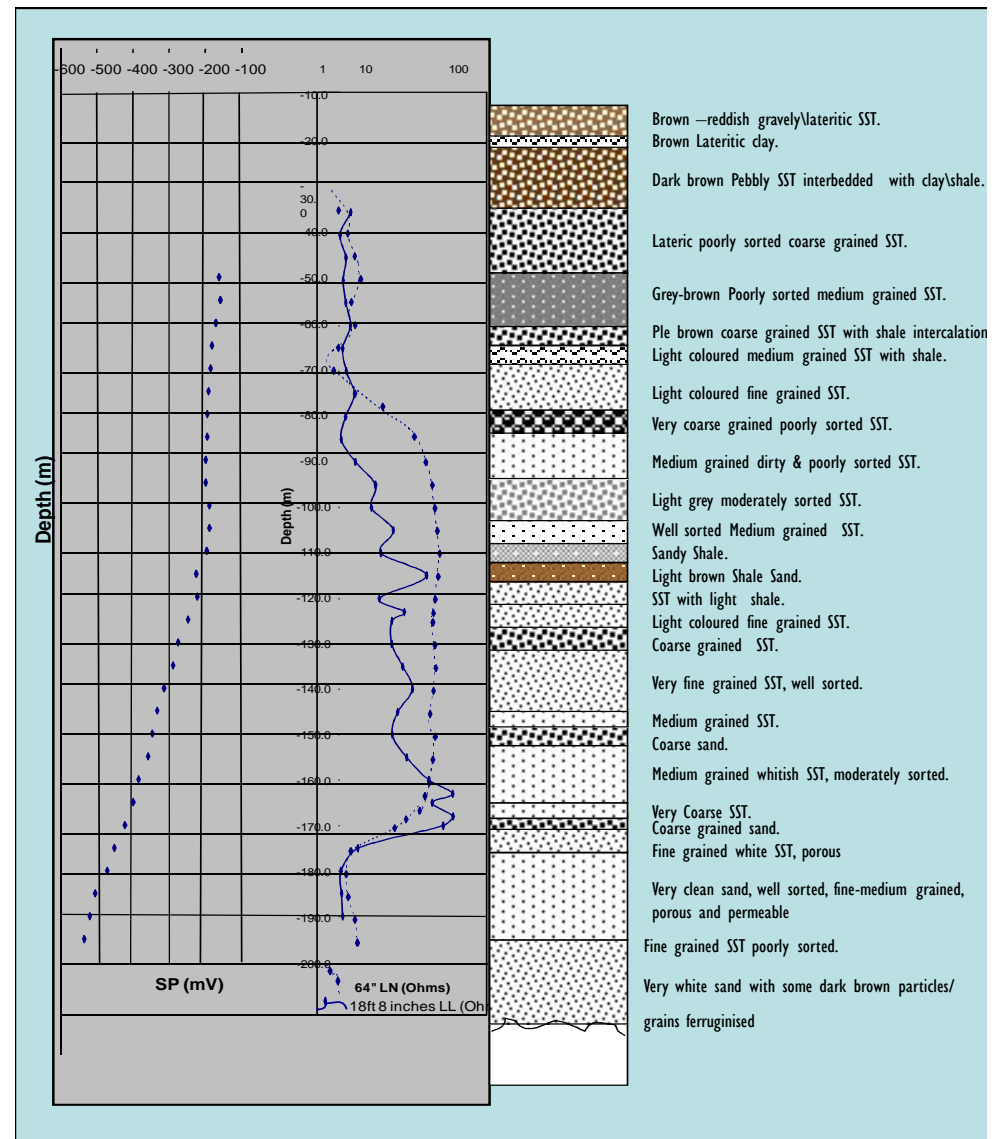

Figure 6: Log and lithological results of the borehole (Z05) at Zenith Bank, Nsukka Town. 


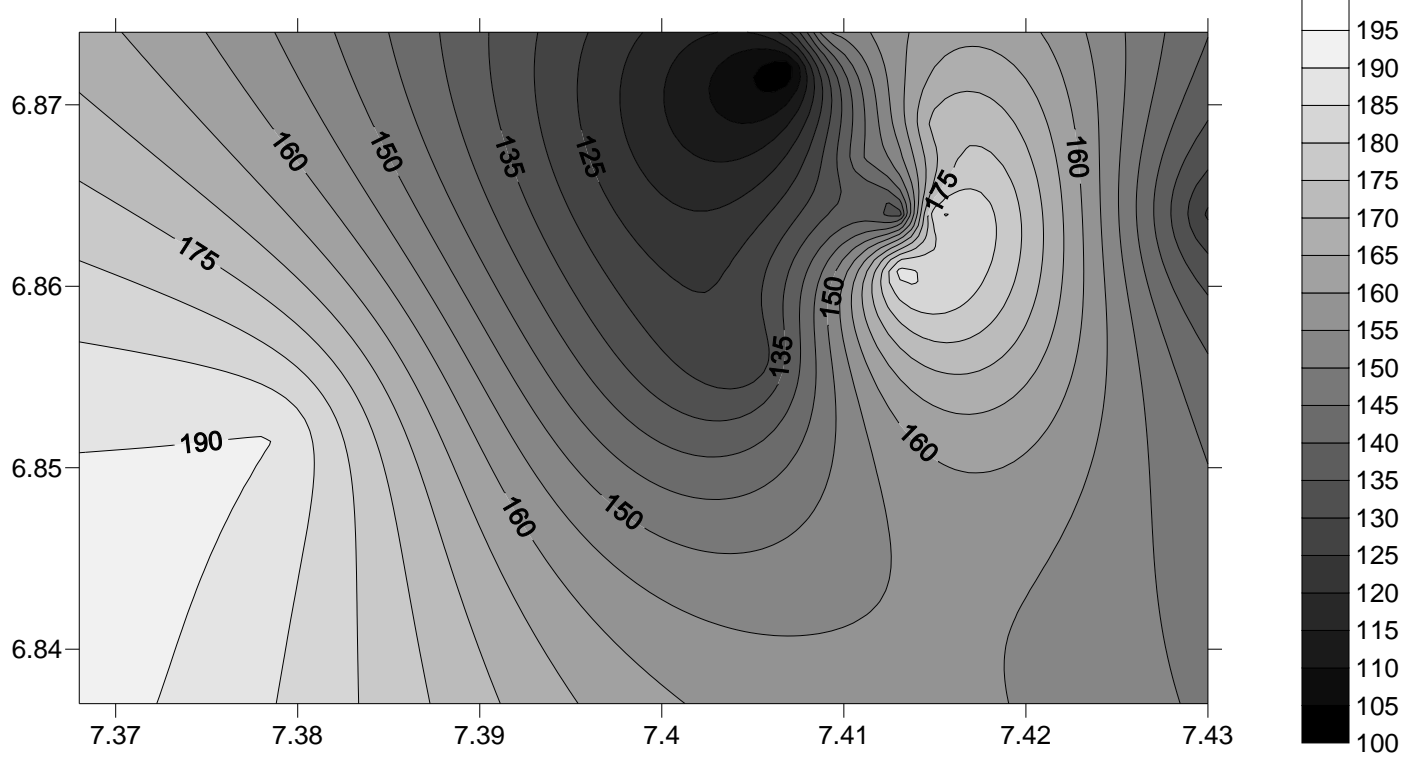

Figure 7: Isopach map of the aquiferous layer(s).
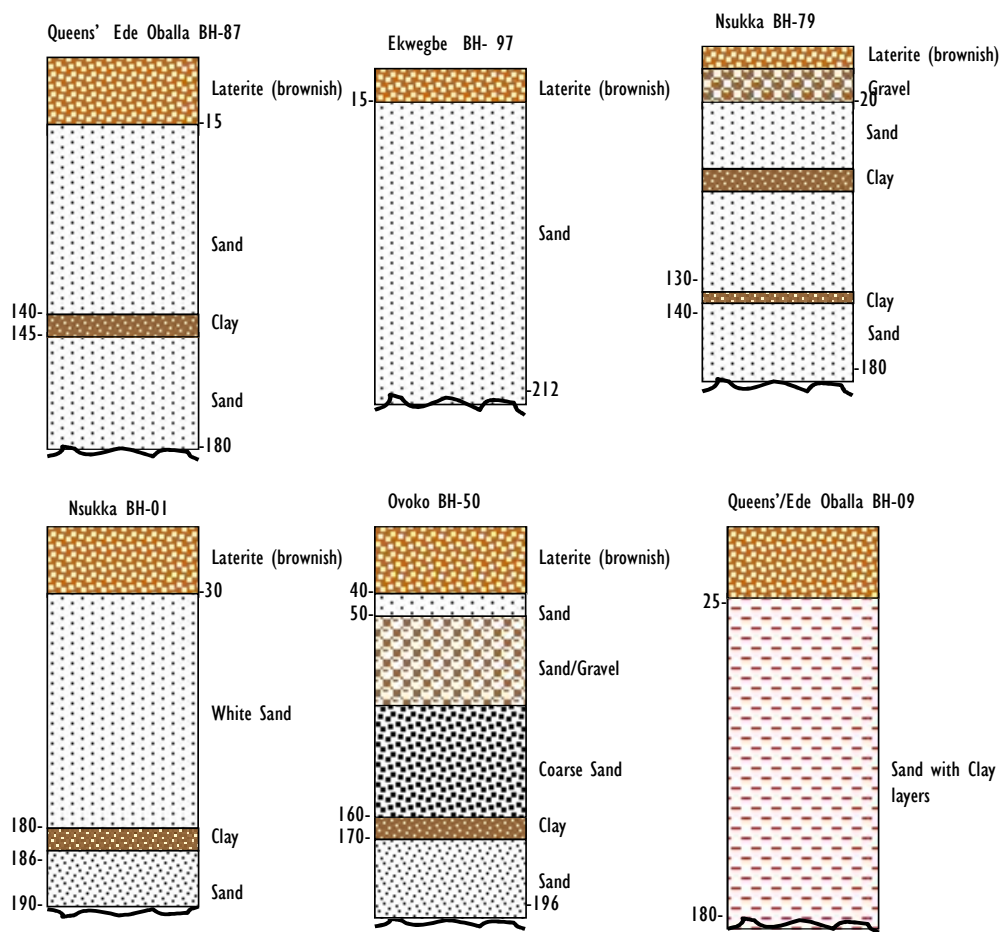

Figure 8: Some other Lithologic logs of boreholes around the study area (Modified after Egboka, 1983) NOTE: Depths are in metres

\section{Borehole and log interpretation}

Borehole geophysical surveys provide an independent evaluation of borehole diameter, stratigraphy, and water-bearing zones, in addition to aquifer and well construction characteristics. This information may be apparent during well drilling due to non-availability of geological records. Hence, borehole logging is a very important means of taking in-situ maxciramontc and ac woll makinn ovaluatinne
The depth to aquiferous layer ranges from $170 \mathrm{~m}$ in Zenith $\mathrm{BH}, 132 \mathrm{~m}$ in Abuja $\mathrm{BH}, 126 \mathrm{~m}$ in Franco $\mathrm{BH}$, to $145 \mathrm{~m}$ in Energy Centre BH (Figs.3, 4, 5 and 6 respectively). These were some of the numerous boreholes drilled in the study area. The aquifer has clean water as was indicated by the SP and Resistivity logs. The Ajali Sandstone aquifer contains some proportion of ironstone (ferruginized) in different Inratinne and donthe of the hnrohnlac Manet of the 
borehole lithologic logs including those in figures 3, 4, 5 and 6 , indicate broadly that within the depths penetrated, the lithologic succession from top is laterite - clay - gravely-sand - sandstone - medium sand (whitish) - ferruginized sand. The borehole apparently did not penetrate the underlying shale unit (Mamu Formation).

\section{Aquifer Parameters(Permeability-k and Hydraulic Conductivity-K)}

Numerous equations and predictive techniques relate intrinsic permeability $(k)$ which depends only on the porous media, to the various properties of the solid media such as grain size, shape factor of the grain, skewness and peakedness of sand grains. Closely related to $\mathrm{k}$ is $\mathrm{K}$, which is a measure of the ability of water to flow through a soil unit. Table 3, lists the average hydraulic conductivity values for the soil types present in the shallow aquifer system. The distribution of the $\mathrm{K}$ of the soils within the layers is the characteristic that is also used in defining the stratigraphy of an area. Generally, within each layer, an average vertical hydraulic conductivity is determined for each well location. The $\mathrm{K}$ values were determined using the new statistical analyses of sand grains of the Ajali Sandstone and results are presented in Tables 3,4 and 7 .

Table 3: Calculated permeability ( $k$ ) values for Ajali Sandstone Aquifer from the selected boreholes

\begin{tabular}{|c|c|c|c|c|c|c|}
\hline \multirow[t]{2}{*}{ S/No. } & \multirow{2}{*}{\begin{tabular}{|l|} 
Borehole \\
Location
\end{tabular}} & \multirow{2}{*}{$\begin{array}{l}\text { Average } \\
\mathrm{d}_{10}{ }^{2}\left(\mathrm{~cm}^{2}\right)\end{array}$} & \multicolumn{4}{|c|}{$\mathrm{Cd}_{10}{ }^{2}\left(\mathrm{~cm}^{2}\right)$} \\
\hline & & & $\begin{array}{l}\text { Harleman et } \\
\text { al. }(1963) \\
C=6.54 \times 10^{-4}\end{array}$ & $\begin{array}{l}\text { Hazen } \\
(1893) \\
C=100\end{array}$ & $\begin{array}{l}\text { Kozeny } \\
\text { Carman in } \\
\text { Bear }(1972) \\
C=64.1\end{array}$ & $\begin{array}{l}\text { Uma et al., } \\
(1988) \\
\text { C = 6.1 }\end{array}$ \\
\hline 1 & Abuja 2 well & 0.002332 & $1.62 \times 10^{-6}$ & 0.2332 & 0.1494812 & 0.0142252 \\
\hline 2 & Franco 3 well & 0.001234 & $1.525 \times 10^{-6}$ & 0.1234 & 0.0790994 & 0.0075274 \\
\hline 3 & \begin{tabular}{|l|} 
Zenith 5 well \\
\end{tabular} & 0.002478 & $8.07 \times 10^{-7}$ & 0.2478 & 0.1588398 & 0.0151158 \\
\hline
\end{tabular}

Table 4: Calculated permeability (k), hydraulic conductivity (K) and Transmissivity (T)values for Ajali Sandstone

\begin{tabular}{|c|c|c|c|c|c|}
\hline \multicolumn{6}{|c|}{ Aquifer from the selected boreholes locations } \\
\hline \multirow{3}{*}{ Aquifer Units } & \multirow{3}{*}{$\begin{array}{l}\text { Method for } \\
\text { obtaining the } \\
\text { Hydraulic } \\
\text { conductivity } \\
\text { values }\end{array}$} & \multicolumn{4}{|c|}{ Aquifer parameters } \\
\hline & & \multicolumn{2}{|c|}{ Permeability (k) } & \multirow{2}{*}{$\begin{array}{c}\begin{array}{c}\text { Hydraulic } \\
\text { conductivity }(\mathrm{K})\end{array} \\
\left(\mathrm{ms}^{-1}\right)\end{array}$} & \multirow{2}{*}{$\begin{array}{l}\text { Transmissivity } \\
\text { (T) }\left(\mathrm{m}^{2} \mathrm{~s}^{-1}\right)\end{array}$} \\
\hline & & $\left(\mathrm{cm}^{2}\right)$ & $\left(\mathrm{m}^{2}\right)$ & & \\
\hline $\begin{array}{l}\text { Abuja } 2 \text { well } \\
\text { Franco } 3 \text { well } \\
\text { Zenith } 5 \text { well }\end{array}$ & $\begin{array}{l}\text { Kozeny } \\
\text { Carman in Bear } \\
(1972) \quad \mathrm{C}= \\
64.1\end{array}$ & $\begin{array}{l}0.1494812 \\
0.0790994 \\
0.1588398\end{array}$ & $\begin{array}{l}1.4948 \times 10^{-5} \\
7.9099 \times 10^{-6} \\
1.5884 \times 10^{-5}\end{array}$ & $\begin{array}{l}164.5973 \\
87.0982 \\
174.9023\end{array}$ & $\begin{array}{l}10534.2300 \\
4790.4000 \\
7870.6000\end{array}$ \\
\hline $\begin{array}{l}\text { Abuja } 2 \text { well } \\
\text { Franco } 3 \text { well } \\
\text { Zenith } 5 \text { well }\end{array}$ & $\begin{array}{l}\text { Uma et al. } \\
(1989) \\
C=6.1\end{array}$ & $\begin{array}{l}0.0142252 \\
0.0075274 \\
0.0151158\end{array}$ & $\begin{array}{l}1.4225 \times 10^{-6} \\
7.5274 \times 10^{-7} \\
1.5116 \times 10^{-6}\end{array}$ & $\begin{array}{l}15.6640 \\
8.2886 \\
16.6444\end{array}$ & $\begin{array}{l}1002.4770 \\
455.8730 \\
748.9964\end{array}$ \\
\hline \multicolumn{6}{|c|}{ Compare with the K of consolidated media (After Marsily, 1986) } \\
\hline S/No & Medium & & $K(\mathrm{~m} / \mathrm{s})$ & & \\
\hline 1 & Coarse gravel & & $10^{-1}-10^{-2}$ & & \\
\hline 2 & Sand and gravel & & $10^{-1}-10^{-5}$ & & \\
\hline 3 & Fine sand, silts, 1 & sess & $10^{-5}-10^{-9}$ & & \\
\hline 4 & Clay, shale, glaci & al till & $10^{-9}-10^{-13}$ & & \\
\hline
\end{tabular}

Where $\mathbf{k}=$ permeability; $\delta=$ Density of water $=\{1000 \mathrm{~kg} / \mathrm{m} 3\} ; \mathrm{g}=$ Earth's gravitational acceleration $=\{9.8 \mathrm{~m} / \mathrm{s} 2\}$; $\mu=$ Viscosity of water $=\{0.00089$ Newton.Sec/m2 Bolz and Tuve (1973) $\}$

2). Transmissivity $(T)=K b$, Where $K=$ Hydraulic conductivity; $b=$ Aquifer thickness 
Table 5: Water level in different locations of the study area

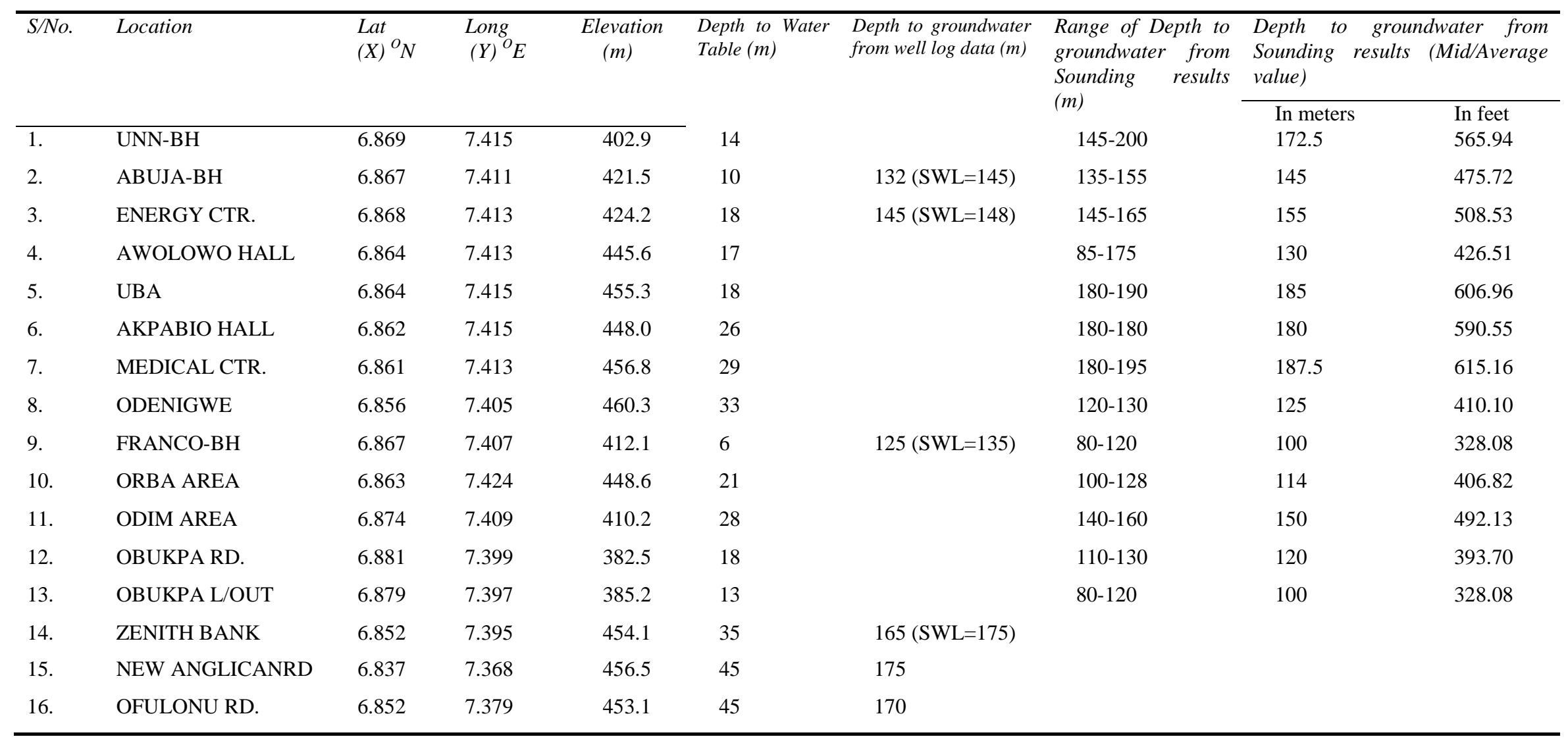


Table 6: Results of the thickness of the aquiferous layers and aquifer yield in the selected boreholes from the study area

\begin{tabular}{|c|c|c|c|c|c|c|c|}
\hline \multirow[t]{2}{*}{ S/No. } & \multirow[t]{2}{*}{ Location } & \multicolumn{6}{|c|}{ Information from Borehole log results } \\
\hline & & $\begin{array}{l}\text { Layer depths } \\
\text { Range h or } \\
\text { z(m)/Aquifer } \\
\text { Thickness } \\
\text { (m) }\end{array}$ & $\begin{array}{l}\text { True } \\
\text { Formation } \\
\text { Resistivity } \\
\text { average } \\
\left(\rho_{\mathrm{T}}\right)\end{array}$ & $\begin{array}{l}\text { Average } \\
\text { Long. } \\
\text { Conductance } \\
\text { S (Siemens) }\end{array}$ & $\begin{array}{l}\text { Average } \\
\text { Trans. } \\
\text { Resistance } \quad \mathrm{T} \\
\left(\mathrm{Ohmm}^{2}\right)\end{array}$ & $\begin{array}{l}\text { Ave. Water } \\
\text { Resistivity } \\
\quad\left(\rho_{\mathrm{w}}-\mathrm{m}\right)\end{array}$ & $\begin{array}{l}\text { Aquifer } \\
\text { Storage/Unit } \\
\text { Vol. OR Yield } \\
\text { OR Vol. of } \mathrm{H}_{2} \mathrm{O} \\
\quad(\mathrm{dW}) \mathrm{m}^{3}\end{array}$ \\
\hline 1. & ABUJA-BH A02 & $\begin{array}{c}132-196 \\
\mathrm{~h}=64\end{array}$ & 1346.31 & 0.123590 & 220726.52 & 134.634 & 4.755 \\
\hline 2. & $\begin{array}{l}\text { FRANCO-BH } \\
\text { F03 }\end{array}$ & $\begin{array}{c}125-180 \\
\mathrm{~h}=55\end{array}$ & 1850.05 & 0.084413 & 285055.20 & 185.01 & 3.057 \\
\hline 3. & $\begin{array}{l}\text { ENERGY CTR.- } \\
\text { BH E04 }\end{array}$ & $\begin{array}{c}148-204 \\
\mathrm{~h}=56\end{array}$ & 2692.28 & 0.065960 & 473719.41 & 269.23 & 2.346 \\
\hline 4. & $\begin{array}{l}\text { ZENITH } \\
\text { BANK- BH Z05 }\end{array}$ & $\begin{array}{c}150-195 \\
\mathrm{~h}=45\end{array}$ & 2409.17 & 0.625668 & 3924324.50 & 240.92 & \\
\hline
\end{tabular}

Table 7: Aquifer Parameters for the Ajali Sandstone (Modified after Egboka, 1983)

\begin{tabular}{|c|c|c|c|c|c|c|c|c|}
\hline \multirow{3}{*}{ Aquifer Units } & \multirow{3}{*}{$\begin{array}{l}\text { Method for } \\
\text { obtaining the } \\
\text { Hydraulic } \\
\text { conductivity } \\
\text { values }\end{array}$} & \multicolumn{6}{|c|}{ AquIfer parameters } & \multirow{3}{*}{$\begin{array}{l}\text { Transmis } \\
\text { sivity } \\
\left(\mathbf{m}^{2} \mathbf{y r}^{-1}\right)\end{array}$} \\
\hline & & \multirow{2}{*}{$\begin{array}{l}\text { Hydraulic } \\
\text { conductivity } \\
\left(\mathrm{cm} \mathrm{s}^{-1}\right)\end{array}$} & & \multirow{2}{*}{$\begin{array}{l}\text { Specific } \\
\text { discharge } \\
\left(\mathrm{m}^{3} \mathrm{~m}^{-2} \mathrm{yr}^{-}\right. \\
\left.\mathbf{1}^{-}\right)\end{array}$} & \multirow{2}{*}{$\begin{array}{l}\text { Ground } \\
\text { water } \\
\text { Velocity } \\
\left(\mathrm{myr}^{-1}\right)\end{array}$} & \multicolumn{2}{|c|}{ Total Discharge } & \\
\hline & & & $\left(\mathrm{myr}^{-1}\right)$ & & & $\left(\mathbf{m}^{3} \mathbf{h r}^{-1}\right)$ & $\left(\mathbf{m}^{3} \mathbf{y r}^{-1}\right)$ & \\
\hline Nsukka Sands & & $9.2 \times 10^{-3}$ & 2190.8 & 17.5 & 49.9 & 109.7 & $9.6 \times 10^{5}$ & $3.2 \times 10^{5}$ \\
\hline Adaoka Sands & Harleman et & $8.7 \times 10^{-2}$ & 11636.8 & 69.8 & 199.5 & 518.3 & $4.5 \times 10^{6}$ & $1.5 \times 10^{6}$ \\
\hline Ochi Sands & al. (1963) & $2.1 \times 10^{0}$ & 656000.3 & 3936.0 & 1900000 & 29223.7 & $2.6 \times 10^{8}$ & $8.5 \times 10^{7}$ \\
\hline Nsukka Sands & Hazen (1893) & $1.4 \times 10^{-2}$ & 4446.6 & 26.2 & 76.2 & 163.8 & $1.5 \times 10^{6}$ & $4.9 \times 10^{5}$ \\
\hline Adaoka Sands & & $5.8 \times 10^{-2}$ & 18164.7 & 109.0 & 311.4 & 808.2 & $7.1 \times 10^{6}$ & $2.4 \times 10^{6}$ \\
\hline Ochi Sands & & $3.2 \times 10^{0}$ & 1000000 & 6130.6 & 17516.0 & 44520.6 & $3.9 \times 10^{8}$ & $1.3 \times 10^{8}$ \\
\hline Nsukka Sands & Kozeny & $2.6 \times 10^{-1}$ & 81993.6 & 492.0 & 1405.6 & 3093.6 & $2.7 \times 10^{5}$ & $9.0 \times 10^{6}$ \\
\hline Adaoka Sands & Carman in & $7.6 \times 10^{-2}$ & 24030.4 & 144.2 & 412.0 & 1069.6 & $9.4 \times 10^{6}$ & $3.1 \times 10^{6}$ \\
\hline Ochi Sands & Bear (1972) & $2.9 \times 10^{-0}$ & 911390.4 & 546.3 & 15623.8 & 40525.1 & $3.6 \times 10^{8}$ & $1.2 \times 10^{8}$ \\
\hline Nsukka Sands & Masch and & $1.7 \times 10^{-2}$ & 5266.5 & 31.6 & 90.3 & 198.6 & $1.7 \times 10^{6}$ & $5.8 \times 10^{5}$ \\
\hline Adaoka Sands & Denny & $1.0 \times 10^{-2}$ & 3153.6 & 18.9 & 54.1 & 140.4 & $1.2 \times 10^{6}$ & $4.1 \times 10^{5}$ \\
\hline Ochi Sands & (1966) & $1.3 \times 10^{-2}$ & 41942.9 & 251.7 & 719.0 & 1872.2 & $1.6 \times 10^{7}$ & $5.5 \times 10^{6}$ \\
\hline
\end{tabular}

The ability of water to flow through a material depends on the $\mathrm{K}$ which depends on the size of the openings, the degree of inter-connection and the amount of open space of the media; as well as the properties of the fluid such as density and viscosity (Freeze and Cherry, 1979; Odong, 2007). The dimension is $\mathrm{LT}^{-1}$ and the unit often employed in statistical analysis of grain samples is $\mathrm{cm} / \mathrm{s}$.

\section{Textural (Grain size) Analysis}

These results are shown in Table 2. As regards the Environment Diagnosis, several methods have been developed in order to use textural analysis to deduce depositional environment and these methods are chiefly empirical in nature, utilizing statistical parameters based upon grain-size frequency distributions (Davis, 1973; Boadu, 2000; Boggs, 2005; Odong, 2007). They fall into these general categories of analysis namely:

a. Univariate device such as signing particular ranges of size, sorting or skewness to particular depositional environments.

b. Type-curve matching where distribution curves are categorized by their slope and form for specific environments.

c. Multivariate tests that combine two or more statistical parameters for separating sets of samples from two or more clearly define depositional environment.

d. Factor analysis which attempts to interprets environment on the basis of mixtures of certain well defined sediment.

\section{Indications from Univariate parameters}

The statistical parameters of grain-size 
distribution have been applied as parameters for delineating the influence of depositional processes. In particular, standard deviation and skewness are considered to be environmentally sensitive indicators while the mean grain-size reflects an overall competency of the transportational dynamic system.

i. Mean Size $(\mathbf{M z})$ : The mean grain-size reflects the overall competency of the transport system. A coarsening upward trend/sequence which was observed in the analysis from the study area may be attributable to a winnowing of finer grain-size population by wave and current action in near shore environment. Bimodality of grain size may reflect deposition in beach environment where differentiation in sorting was produced by swash and backwashcurrents. Conversely, a fining upward sequence is commonly attributed to fluvial action and possibly results from lateral migration of fluvial channels. Abrupt variations in mean-size are commonly related to rapid changes in hydraulic energy commonly associated with tidal and wave actions.

ii. Sorting $\left(\sigma_{1}\right)$ : Sorting indicate the fluctuation in kinetic energy (velocity) of the depositing agent. An up section improvement in sorting within the sand unit may reflect a change of environment. This is typical of the transition from deeper water to shallower water (i.e. from upper shore face to fore shore). Fluctuating sorting values often results from differences in water turbulence and variability in current velocity. Poor sorting reflects smooth stable flow. Most of the results, range from moderately sorted $(0.724)$ to very-well sorted $(0.284)$ as shown in Table 2.

iii. Skewness (Ski): This measures the asymmetry of the frequency distribution. If skewness is negative, the sample is coarsely skewed and vice versa. A coarsely skewed sample implies that the velocity of the depositing agent operated at a higher value than the average velocity for a greater length of time than normal. Coarse-skewed sands are more common in littoral, beach and tidal inlet environment where the winnowing action of waves and tidal currents are more dominant. Fine-skewed sands are typical of sheltered quiet water areas and in deep water, where bottom currents or wave-base surge does not disturb bottom sediments. Near symmetrical skewness reflects that broad spectrum of populations are present in the sample, for the study area. From the result, A02, strongly fine skewed predominate at the top while the base show fine skewed. F03 vary considerably from fine skewed (0.298) to near symmetrical (0.077).

iv. Kurtosis $\left(\mathrm{K}_{\mathrm{G}}\right)$ : Is not an environmentally diagnostic parameter. However, flat curves of poorly sorted sediments are platykurtic while strongly peaked curves of good sorting are leptokurtic. The kurtosis results for the samples show very leptokurtic to mesokurtic.

Sedimentary structures such as bedding, lamination, cross strata, biogenic structures, ripple marks, etc abound in the area. They are generated by the inherent sedimentary processes like fluid flow, sediment gravity flow, soft sediment deformation, etc. However, they reflect environmental conditions that prevailed at or very shortly after time of deposition. Therefore they are used by geologist as a tool for interpreting ancient depositional environment, and for development of a rock sequence in an area of complex folding, and also deducing the paleocurrent pattern and palaeogeography.

\section{Aquifer parameters, Water Resources Evaluation and Management}

The results are summarized in Tables 3, 4, 5 and 7. From the table above, it implies that the sands of the graded, false bedded sandstone facies have high permeability $(\mathrm{k})$ with values from 0.00753 to 0.01512 $\mathrm{cm}^{2}$, and hydraulic conductivity $(\mathrm{K})$ from 8.2886 to $16.6444 \mathrm{~m} / \mathrm{s}$.

In the study area, stratigraphic analyses of well lithologic logs reveal the presence of at least four layers of contrasting hydraulic conductivity, making the Ajali Sandstone Aquifer homogenous and anisotropic.

There is less/ inadequate surface water in Nsukka area hence, little or no drainage network but there are several springs issuing from the flanks of the ridges of the several hills in the study area. Most parts are underlain by porous and permeable sandy units and so are devoid of any surface water bodies, due to the absence of intervening shale layers for infiltrating rainwater, and the deep water table. This is typical of all the areas where the Ajali Sandstone is the direct underlying formation, or the depth to the formation is shallow. Conversely, few ephemeral springs arise from the interception of few sand lenses (perched aquifers) that exist in the areas dominated by shales and laterites of the Nsukka Formation.

However, these springs do not produce/supply enough water to meet the demand of the people in the area. This shortage of water, despite the high annual rainfall; about $167.5 \mathrm{~cm}$ (Groove, 1951), therefore presents a problem in the area. This water deficiency results from the combination of some factors including, the prolonged dry season and the high permeability of the strata which allows the rainwater to infiltrate to great depth, as was also noted in the work published by Egboka (1983).

In order to solve the problem of water supply and also to improve the quality of drinking water, several boreholes were sunk in the study area (including the University Community and the Nsukka metropolis). These boreholes tap the underground water from the main (Ajali Sandstone) Aquifer which had been observed to fluctuate in level seasonally. Rainfall is the major source of recharge in the area. A comprehensive survey of the potable water boreholes in the study area was made and the lithologic logs and electric logs of most of them were collected. Some of the logs are incomplete. All attempts to collect pumping test data proved unsuccessful.

Perched aquifers, water table and confined aquifers have been defined from drill logs and the outcrops. The drill logs were prepared from boreholes data at sites shown earlier. Most of the lithological logs have lateritic caps varying in thickness from $10 \mathrm{~m}$ to $95 \mathrm{~m}$ as vindicated from the studies made by Egboka (1983), Nwankwor et al., (1988), and Akudinobi and Egboka (1996).

Some of the boreholes show a multi-aquifer system separated by clayey or sandy-clayey aquitards. The boreholes sited at the sandy geologic unit of the Ajali Sandstone struck aquifers at various depths. The 
depths of penetration of the boreholes range between $120 \mathrm{~m}$ and $220 \mathrm{~m}$. Most of these were terminated in sandy layers. Deeper drilling would have encountered more aquiferous horizons, and reduce the present under utilization of the aquifers. All the wells drilled as at the time of the study were screened at a section of one aquifer. It would be more advisable to screen two or more aquifers and tap all of them in a coupled manner to provide a better well-yield from the aquifer system.

\section{Groundwater flow and Aquifer Parameters}

Two flow systems were identified, and they were more or less topography driven. The first upper localized perched system (LPS) resulting from the entrapment of vertical flow through the rigolithic Nsukka Formation by the underlying impermeable members, usually clay or shale.

The second flow system is the regional groundwater flow system (RGS) which originates from a surface water/groundwater divide at the eastern portion, including Orba, Ede-oballa and Opi. Here flow divergence is influenced by both topography and medium anisotropy. A geostatistical model of the hydraulic conductivity field indicates that about every $50 \mathrm{~m}$ vertical distance within the saturated Ajali Sandstone Aquifer is a conductivity interface. Also the divergence of flow south-westwards and northwestwards shows the effect of refraction of flow line away from main flow direction due to underlying layers of higher permeability and the Darcy velocity (specific discharge) varies from $0.02 \mathrm{~m} /$ day at the east to $0.06 \mathrm{~m} /$ day at the west while linear velocity follows the same trend from $0.05 \mathrm{~m} /$ day to $0.16 \mathrm{~m} /$ day. Transmissivity $(\mathrm{T})$ is highly variable from $1896 \mathrm{~m}^{2} /$ day at Abuja $\mathrm{BH}$ to $2219.17 \mathrm{~m}^{2} /$ day at Franco $\mathrm{BH}$.

The hydraulic conductivity is equally variable from $0.086 \mathrm{~m} /$ day to $25.72 \mathrm{~m} /$ day. The effect of partial penetration and non-uniform aquifer thickness accounts for this variability. The area within the elevation of 140m-220m above sea level including lbagwa, Obukpa, Onuiyi, Ede-oballa and Opi are associated with high yield.

With regard to environmental issues, most streams and land surfaces are polluted due to improper sewage disposal, landfills, mining and some industrial activities in the study area. Consequently, the few surface water bodies and groundwater have been contaminated.

However, as a result of nearness of overlying red-earth in some places, iron oxides are leached into the aquifer which has a staining effect and may contaminate the water. Also, contaminations come as a result of dissolved materials filtering into the ground. In the case of perched aquifer over lashed by lateritic red earth, there is no confining impermeable upper layer to prevent direct drip-down of contaminants.

Prevention of erosion is very important and should involve the checking of surface run-off by construction of drainage channels. Some practices like poor farming methods, poor construction work, should be addressed properly. Above all, education of the masses on effects of erosion in urban planning and development should be improved upon.

Water pollution can be prevented by primary and secondary treatment of sewage before the water is allowed to drain to the water table. Recycling of waste by industries should be encouraged and indiscriminate waste disposal should be controlled. Adequate toilet facilities should be provided and promoted to reduce indiscriminate defecating in waters, streams and rivers.

\section{CONCLUSIONS}

In major parts of the study area, Nsukka Formation occurs as patches of hills and relatively highlands while the Ajali Sandstone predominates in the lowlands and valleys. The aquifer systems also characterize the conditions of the underground flow.

This study which included the well log analysis and the analysis of the borehole samples also with the use of the new statistical grain-size method, have provided information on the thickness and characteristics of Ajali Sandstone and probably, the depth to groundwater at several locations of the area. Results have also shown that aquifer parameters like: permeability $(\mathrm{k})$, hydraulic conductivity $(\mathrm{K})$, transmissivity $(\mathrm{T})$, and Specific yield have high values in most parts. This has inferred that the area has thick and prolific aquiferous zone(s).

All the wells drilled as at the time of the study were screened at a section of one aquifer. It would be more advisable to screen two or more aquifers and tap all of them in a coupled manner to provide a better wellyield from the aquifer system. Based on standing water analysis, the water from the boreholes in the area is portable and of good quality both for domestic, industrial and agricultural purposes. The lack of very large surface water and ground water reservoirs within most of the areas in Nsukka metropolis is already limiting water resources development and agricultural activities in the area.

All these information are thus going to be relevant for further hydrogeophysical studies and for future development of an effective water scheme for the area and possibly beyond, to other areas underlain by the Ajali Sandstone.

\section{ACKNOWLEDGEMENTS}

The authors acknowledge the assistance of Ezim Jeremiah, Ozor Chuks, and Dr. Pius Aghamelu during the fieldwork and data collection. Mrs. Ifeyinwa of Geology laboratory assisted in the textural analysis and Prof. Goddy A. Onwuemesi of the Geological Science Department of Nnamdi Azikiwe University, Awka proofread the initial draft of the manuscript. They are warmly appreciated.

\section{REFERENCES}

Agagu, O. K., Fayose, E. A and Petters, S. W., 1985. Stratigraphy and Sedimentation in the Senonian Anambra Basin of Southeastern Nigeria: Nig. Journal of Mining. Geol., 22, (1 and 2): 25-35.

Akudinobi, B. E. B and Egboka, B. C. E., 1996. Aspects of Hydrogeological Studies of the Escarpment Regions of Southeastern Nigeria: Water Resources J. NAH, 7, (1and 2): 12-25.

Amajor, L. C., 1984. Sedimentary Facies Analysis of the Ajali Sandstone (Upper Creataceous), Southern 
Benue Trough: Nigerian. Journal of Mining Geol., 21, (1 and 2): 171-176.

Banerjee, I., 1979. Analysis of Cross bedded Sequences: An example from the Ajali Sandstone (Maastrichtian) of Nigeria. Quarterly Journal Geol. Min. Metal Soc. India, 51, (2): 6981.

Boadu, F. K., 2000. Hydraulic Conductivity of Soils from Grain-Size Distribution: New Models; Journal of Geotechnical and Geo-environmental Engineering.

Boggs, S. Jr., 2005. Principles of Sedimentology and Stratigraphy: (4 ${ }^{\text {th }}$ Edition) Prentice-Hall, Inc., New Jersey, 33-487.

Davis, W. C., 1973. Statistical and Data Analysis in Geology: John Wiley and Sons, Inc., New York, U.S.A., 458.

Egboka, B. C. E., 1983. Analysis of the Groundwater Resources of Nsukka Area and Environs, Anambra State, Nigeria: Journal of the Nigerian Mining and Geosciences Society; 20, (1 and 2): $1-16$.

Freeze, R. A and Cherry, J. A., 1979. Groundwater: Prentice Hall Inc., Englewood Cliffs, New Jersey, 604.

Harleman, D. R. E., Melhorn, P. F and Rumer, R. R.,

1963. Dispersion-Permeability Correlation in Porous Media: Jour. Hydraul. Div. American Soc. Civil Eng., No. HY2, 89, 67-85.

Hazen, A., 1893. Some Physical Properties of Sands and Gravels, with Special Reference to their Use in Filtration: $24^{\text {th }}$ Annual Report, Massachusetts State Board of Health, Pub. Doc. (34): 539-556.

Inyang, P. C. B., 1975. Climatic Regions of Nigeria in Maps, Ethopia Publishing Company, Benin, Nigeria, 1-30.

Kogbe, C. A., 1989b. The Cretaceous and Palaeogene Sediments of Southern Nigeria, In: Kogbe, C.A., (Editor): The Geology of Nigeria: Rock View Publishers, Nigeria, Lagos, 325-334.

Ladipo, K. O., 1986. Tidal Shelf Depositional Model for Intertidal Sandstone, Anambra Basin, Southern Nigeria: Journal of African Earth Science, 5, 177-185.

Murat, R. C., 1972. Stratigraphy and Palaeogeography of the Cretaceous and Lower Tertiary in Southern Nigeria. In: T.F.J. Dessauvagie and A.J. Whiteman (Editors), African Geology,
University of Ibadan Press, Ibadan Nigeria; 251266.

Nwajide, C. S and Hoque, M., 1976. Laterization and Nigerian Laterites: Journal of Indian Academy of Geosciences, 19, (1): 1-13.

Nwajide, C. S and Reijers, T. J. A., 1996. Geology of the Southern Anambra Basin; In: T.J.A. Reijers (Editor), p. 133-148: Selected chapters on Geology, SPDC Warri, 197.

Nwajide, C. S., 2006. Anambra Basin of Nigeria: Synoptic Basin Analysis as a Basis for Evaluating its Hydrocarbon Prospectively. In: Okogbue, C.O. (Ed.), Hydrocarbon Potentials of the Anambra Basin: Geology, Geochemistry and Geohistory Perspectives. Proceedings of the First Seminar Organized by the petroleum Technology Development Fund (PTDF) Chair in Geology, University of Nigeria, Nsukka, May 1215, 2005, 1-46.

Nwankwor, G. I., Egboka, B.C.E., and Orajaka, I.P., 1988. Groundwater Occurrence and Flow Pattern in the Enugu Coal-Mine Area, Anambra State, Nigeria; Hyrological Sciences-Journal-des Sciences Hydrologiques, 33, (5): 465-482.

Odong, J., 2007. Evaluation of Empirical Formulae for Determination of Hydraulic Conductivity based on Grain-Size Analysis: Journal of American Science, 3, (3): 54-60.

Ofomata, G. E. K., 1973. Aspect of the Geomorphology of the Nsukka-Okigwe Cuesta: East Central State, Nigeria. Bulletin De' Ilfan: 25, (A3): 489501.

Onwuemesi, A. G., 1990. Hydrogeophysical and Geotechnical Investigation of the Ajali Sandstone in Nsukka and Environs with Reference to Groundwater Resources and Gully Erosion Problems: Water Resources J. NAH, 2, (1): 70-76.

Uma, K. O., Egboka, B. C. E and Onuoha, K. M., 1989. New Statistical Grain-Size Method for Evaluating the Hydraulic Conductivity of Sandy Aquifers: Journal of Hydrology, Amsterdam, 16, 108, 367-386. 